\title{
Country Branding and Country Image: Insights, Challenges and Prospects. The Case of Estonia
}

\author{
Siiri Same \\ Maria Claudia Solarte-Vasquez \\ Tallinn University of Technology \\ Akadeemia tee 3, \\ Tallinn 12618, Estonia \\ E-mail: siiri.same@gmail.com \\ E-mail: mcsolartev@gmail.com
}

Abstract: Gaining understanding about customers'mindset and information on their experiences is a precondition for the formulation of an effective country branding strategy. What potential tourists might learn and how they can be made to feel about a place can help small and not very well-known countries compete with bigger and more popular tourist destinations. The article focuses on the effectiveness of Brand Estonia and claims that it is still a challenge, despite the existence of an ongoing strategy. It also favors the revision of the brand identity selection and the promotion of Estonian brand, and supports a customer-based approach for their assessment. Documentary and empirical evidence show that the image of Estonia among its most important target audiences in the field of tourism does not match the Estonian brand identity. The gap in-between was evidenced by the results and content analysis of 24 in-depth interviews made with a selected group of people well acquainted with the country as well as some branding experts. This article contributes to the existing case study literature with findings that also manifest opportunities to strengthen the country brand, if its formulation develops a realistic brand identity and its promotion is based on accurate, unique and appealing ideas. It proposes academic support to innovative or alternative concepts for the country branding, and comments on applications of this study to more specific fields and further research.

Keywords: country branding, country image, destination, Estonia, experience, place marketing 


\section{Introduction}

Place is a generic term that encompasses countries, regions, cities and specific locations. However, theoretical conceptualizations in the social sciences have turned it into an important and complex notion that refers not only to its geographical meaning. A sociological and anthropological dimension considers cultural, social and personal imprints on places (Cuba \& Hummon, 1993); a psychological approach focuses on the cognitive and emotional relationships that individuals establish with their environment (Stokols, 1995), also on the identities and attributions that influence people's perceptions and how they construct significance around places (Folkes, 1988); and marketing assigns relevance to places for strategic marketing management and development purposes, particularly in the way they affect image and consumer behavior. Country brand compares with corporate brand and in this analogous conception is subject to management in the most popular research topics of place brand management in literature: brand strategy, identity, positioning, brand associations, image, and performance (e.g., Anholt, 2007; Ashworth \& Kavaratzis, 2010; Hankinson, 2009; Kotler \& Gertner, 2002; Morrison, 2013; Pike, 2004). This interdisciplinarity has implications that reflect on the growing amount of academic and empirical research about country brand management. Anholt (2007, cited in Moilanen \& Rainisto, 2009, p. 7) puts it clearly: "Place branding is the management of place image through strategic innovation and coordinated economic, commercial, social, cultural, and government policy". Other implications regard not only the multidimensionality of the concept in itself, but also the physical object of analysis.

Country is not one static political entity with defined borders but it is also formed by smaller differentiated units with their own characteristics. Any of these could constitute a decisive element for the creation of a unique brand and affect the performance of the whole. While a brand is part of the deliberate creation of a product (Nikolova \& Hassan, 2013), perceptions of it take place at the personal level, depending on the capacity, competence and adopted conventions of each individual. Attitudes are formed therefore far from the direct control of brand experts or managers. Appreciations of meaning and value are subjective and multifaceted processes, difficult to trace and verify. This is how perceptions about countries are embedded with beliefs and why emotions turn into attitudes, in the same way it happens about other people, products, ideas, or companies. Kotler and Gertner (2002, p. 249) assure that "brands incite beliefs, evoke emotions and prompt behaviours." Developing innovative, sustainable and effective brand strategies is beneficial to promote tourism, but 
not only; as Moilanen and Rainisto (2009) have argued, the implementation of a good country brand is of far reach. It has a positive impact on businesses, financial markets, public diplomacy, citizens' identity and their self-image as well. Garcia, Gomez and Molina (2012) relate to Kamakura and Russell (1993) to describe the investment that a country makes when developing an effective brand, explaining that brand equity occurs when customers familiar with the brand have formed favorable, solid and unique associations with it. They call it "customer-based brand equity" and it is a notion linked to country image.

Significant problems with the Estonian branding process and its impact have been noticed in earlier research (see section 4.1). The article elaborates on these, and presents the most current challenges and opportunities that the Estonian brand is facing. It departs from the assumption that a better understanding of the relationships between countries and people is necessary for the development of a strategy for an effective country brand, its management, sustainability and evolution.

The following pages will present a qualitative assessment of the effectiveness of the Estonian brand, based on an empirical analysis of the country branding process and the opinions of the target audience represented in a set of 24 interviews. The aim is to learn about people's perceptions of the brand, their match with its formulation premises, Estonia's image abroad, and how to enhance the experiences of it. The country brand concepts, symbols, slogans, and its sign are used as referents.

This article is restricted to the first stage of a wider work that seeks to support the renewal of the branding strategy for the country, built on accurate and updated understanding of the product (Papadopoulos \& Heslop, 2002; Warnaby \& Medway, 2013) and its stakeholders' roles, engagement and expectations. The specific threefold research objective includes: 1) a systematic revision of earlier studies, the content of the Estonian brand strategies, and the brand manual; 2) an analysis of the interviews on country branding and country image; and 3) a proposal on categories for the construction of a conceptual framework applicable to future research. It starts by confirming arguments from the previous initiatives with updated, deeper and more complete research on recent creditworthy materials; then analyzes data, identifies problems and opportunities, and introduces the phase that should follow. This long-term project must be performed in a holistic manner with an emphasis on qualitative methodologies but alongside data collection that could also be subject to quantitative assessment. 


\section{Theoretical background}

Dinnie (2008, p. 15) defines country brand as "the unique, multi-dimensional blend of elements that provide the place with culturally-grounded differentiation and relevance for all of its target audiences". Country brand may be defined as "a network of associations in the consumers' mind based on the visual, verbal, and behavioral expression of a place, which is embodied through the aims, communication, values, and the general culture of the place's stakeholders and the overall place design" (Braun \& Zenker, 2010, p. 5).

Two fundamental constructs on country branding are brand identity and image. Brand identity is a choice that "represents the vision of how the destination should be perceived in the marketplace, with the aim of achieving differentiation" (Pike \& Page, 2014, p. 211). It should refer to what the country really is and how it chooses to be defined (Same, 2012). In contrast, image reflects how the public perceive the country; image might or might not match reality or identity, in addition it varies from person to person. The literature also points to a third element in branding theory-brand positioning (e.g., Aaker, 2002; Kapferer, 2012; Pike \& Page, 2014). Blain, Levy and Ritchie (2005) hint that brand positioning involves destination's name, logo, and value propositionthe slogan. Pike (2012, p. 101) states that "brand positioning is the attempt to enhance congruency between brand identity and brand image".

Marketing theory has established that the link between identity, experience, and image is fundamental in place marketing (Govers \& Go, 2009). Here is where the importance of country branding activities attempting to reduce the gap between identity and image resides. Branding experts and scholars (e.g., Hankinson, 2009; Kapferer, 2012; Keller, 2008; Kotler \& Gertner, 2002) agree on the importance of working on the identity first, as it turns into the most persuasive and effective tool for the formulation of a powerful branding strategy, and the differentiation of the country brand messages and its image. The identity is at the core of all constructs and once chosen, developed or set, needs to match the perception of people: locals, potential visitors, etc. At this level uniqueness plays a fundamental role in creating a comparative and durable advantage. Success stories often mentioned in the literature are Australia, Spain, Ireland, New Zealand, Virginia ("Virginia is for Lovers"), New York ("I love NY"), etc.

According to Anholt (2007, p. 5), place brand managers can influence the brand image - "the perception of the brand that exists in the mind of the consumers or 
audience." Pike (2012, p. 101) says that brand image has "an external market orientation, and stands for the actual image held by consumers." In that light, research investment is critical to understanding how the country is perceived as are its products and services, what is the image of the country and the quality of its offerings, as Elliot, Papadopoulos and Szamosi (2013) have also emphasized. One could add that this also measures the consistency and veracity of the brand and its derived constructs and its capacity to promote its products. A country brand is effective when its image matches the identity promoted. The state should be engaged in these activities and assist with policies given the impact on the social and economic development that can be expected from a successful country branding. It also represents the country and helps deliver to customers what the brand offers: experiences and services that can only be obtained in "there".

Studies and research have also monitored the evolution of customer reactions, views, sentiments and preferences. This is important, given that the differentiating features that set a country apart from others do not have a permanent impact on the public; customers' interests are changing (Pike, 2012). Country image is never fixed or immobile (Brown et al., 2006; Kavaratzis \& Hatch, 2013). Furthermore, not all important and differentiating attributes of a place, even if accurate, are appealing to people, or consistently taken into account when deciding on travel destinations. Each person develops own representations about places and focuses selectively on factors that can be real or perceived. They are influenced by beliefs, ideas, attitudes, impressions, opinions and other cultural constraints (Myers \& Alpert, 1968; Beerli \& Martin, 2004; Nicoletta \& Servidio, 2012). An additional constraint to consider is that mistakes and confusion cannot be completely prevented in communication with a wide audience. For example, stereotyped images are much easier to perceive and remember because they are simplifications of a much more complex reality.

Place branding is an encompassing expression that is also the preferred umbrella term in the marketing literature on this field. Country branding is covered by it. Fetscherin (2010) further classified country branding into four main subjects: country image or country-product image (Agarwal \& Sikri, 1996); country identity (Hall, 2002; Keillor \& Hult, 1999); destination branding (Hankinson, 2009); and country of origin (Roth \& Romeo, 1992; Nebenzahl \& Jaffe, 1996). This list is not all-inclusive, for instance nation branding (Anholt, 2007; Dinnie, 2008) and in some cases region branding (Andersson, 2007; Hall, 1999) could also be added to it. 
Although country image research is one of the most widely reported in the tourism literature, it has remained descriptive and based on small convenience samples (Gertner, 2011). Pike and Page (2014, p. 212) argue that in destination marketing, the main concern has been solving management problems by "fragmented applied research approach rather than theory building." Pike had found in an earlier review of 264 destination image studies (Pike, 2002; 2007), that more than half of them referred to one destination only. The majority of previous studies have focused on case studies (Botterill \& Platenkamp, 2012), for example, based on countries such as Canada (Hudson \& Ritchie, 2009), Yugoslavia (Hall, 2002), Spain (Gilmore, 2002), Latvia (Endzina \& Luneva, 2004), England (Wetzel, 2006), New Zealand (Morgan, Pritchard \& Piggott, 2002), and Denmark (Therkelsen, 2003). In qualitative research into tourism marketing, the most used methods are interviews and focus groups.

\section{Methodology}

A qualitative research was performed on the basis of 24 semi-structured in-depth interviews conducted between April 2012 and January 2014. The purpose was to understand how foreigners perceive and think of the case study proposed: Estonia and its branding and image. People from the European Union, especially in the priority markets for tourism were the first group considered. ${ }^{1}$ To include a wider perspective, participants from America and Oceania were also invited. ${ }^{2}$ Criteria for the selection sought to include people that have been to Estonia several times, or have been residing in the country for more than five years. Importance was assigned to the fact that they could be familiar with the brand and have an opinion on most of its features. Seventeen interviews were conducted with foreigners living abroad, four with foreigners living in Estonia, and three with representatives of Enterprise Estonia, the country destination marketing organization (DMO). They all have higher education degree. Six of them are branding experts: academics or experienced marketing professionals.

This study has been proposed as an assessment of perceptions similarly to Hankinson's (2009) "of people who can provide ideas and insights" on the issues under consideration, in an "experience survey"-like inquiry. Perceptions cannot be evaluated with quantitative methodologies, as far as their meaning and extent

Finland, Sweden, Norway, Russia, Germany, the UK, Latvia, and Spain.

2 The group includes participants from Finland, Sweden, Norway, Latvia, Denmark, the UK, Hungary, the USA, Australia, Canada, Japan, and Scotland. 
is concerned. The interviews propose a dialog, are open to debate and highly dependent on context: the people involved, expertise, subject, and field. Their aggregate does reveal insight. For marketing research, the limitations of science are too restrictive to deliver convincing conclusions on human perception, hence the increasing importance of using qualitative methods (Bellenger, Bernhardt \& Goldstucker, 2011; Creswell, 2012).

All the interviews lasted between 60 and 95 minutes. The sign, slogan and pattern were shown for guidance. The interview guide consisted of 26 questions with sub-questions. The interviewer was free to move from one topic to another regardless of their sequence, and avoided interruptions to become conversational and help the dialog. When the interviewees volunteered information that was not within the framework of the study but seemed useful, additional questions were asked. The sample reached saturation when responses became redundant, and additional interviews would not contribute with any more relevant information to the records (Patton, 2002). All sessions were recorded and transcribed.

Secondary data was also used: the marketing strategies, the brand manual and publications on previous research. These materials were analyzed on their substance. Document analysis was used because case studies using multiple sources of evidence could be rated higher in terms of overall quality (Yin, 2009).

The content analysis followed the standard procedures of categorization, and coding (Hsieh \& Shannon, 2005; Mayring, 2000). In-depth interviews yield rich amounts of data that were helped with software screening methods. The transcripts were additionally processed using Atlas.ti ${ }^{3}$ to group the codes and verify that all possible categories were taken into consideration.

$3 \quad$ Available at www.atlasti.com. 


\section{Findings}

The findings will first review earlier research and marketing strategies, and proceed with a categorized account of the interviews' content on Estonia's image, Estonian brand, potential for country branding, and Estonian experiences.

\subsection{Studies on Estonia's image and the development of Brand Estonia}

The Estonian brand initiative was prompted by the exposure that the country received after winning the Eurovision song contest in May 2001. In December, a series of five qualitative survey reports ${ }^{4}$ were commissioned by Enterprise Estonia (DMO), to begin the process of developing a brand concept. A brand manual was ready in 2002; the brand itself was created by Interbrand, the same company that discussed and prepared the surveys' guidelines. Five in-depth telephone interviews were conducted in five countries and this became the baseline for the analysis. The interviewees were tourists who had visited Estonia. From their opinions, analyzed by TNS Emor, it was drawn that common symbols of the country among respondents were Tallinn's Old Town and architecture, and that people knew little about Estonia, especially in Germany and the United Kingdom. In 2003, Erm and Arengu (2003, p. 24) published a work in which they stated that "no public testing took place" and that "the concept and creative solutions were prepared on the basis of Interbrand's internal know-how." The brand was launched inside the country at a small scale. Unwelcomed and lacking support by the public, it also received criticism because of its high cost (860,000 euros) (Moilanen \& Rainisto, 2009, p. 66). Estonia became the first former Soviet country to develop its country brand (Szondi, 2007).

The official brand manual expanded on the brand strategy: "designed to launch and establish Estonia as a unique, fascinating and positively transforming country." It described Brand Estonia as multidimensional with the sign 'Welcome to Estonia' (WTE), slogan 'Positively transforming', pattern, and distinct colors, photography, and typography. The sign was created for a campaign only, of a limited use of up to five years, and aimed at becoming the brand signature/ trademark of the stories that elaborated on the positive transformation, certifying their authenticity. It was supposed to visually represent change; emphasis was

4 The surveys were published under the following titles "Image of Estonia in Finland and Sweden", "Image of Estonia in the United Kingdom", "Image of Estonia in St. Petersburg", "Summary report Germany, In-depth Explorations with German Tourists, Investors and Importers in Estonia", and "Attractions and Values of Estonia through the Eyes of Local Inhabitants". 
added to the European abbreviation of the country (EST) and the irregular shape the words formed. WTE should have been inviting to the audience and communicate openness, accessibility and proactivity. The expression itself was supposed to confirm Estonia's unique positioning: a country where expectations would be transformed.

In 2003, the government ceased to provide financial support for the maintenance of the brand (Moilanen \& Rainisto, 2009). This soon confirmed that country branding can be affected by politics and thus be challenging for DMOs.

The next documented study took place in 2008. GfK Custom Research Baltic, on request of Enterprise Estonia, tested the awareness, recognition and reputation of the WTE sign among Finnish, Swedish, German, Norwegian and British residents. In Germany and the United Kingdom, GfK conducted omnibus study whereas in the other countries 1,000 responses were collected from participants through online questionnaires. The findings showed again that the awareness and recognition level of the sign was low. On its reputation the results were no better: most respondents considered it nondescript, it aroused no interest, and did not seem innovative. In addition, it was not associated with quality, friendliness and/or trustworthiness. British respondents even considered the sign to carry negative connotations.

Also in 2008, Enterprise Estonia ordered a domestic quantitative marketing survey from the Estonian market research company Turu-uuringute AS. The survey was divided in two: the first, on the opinions of Estonian residents about the sign and the country's reputation abroad (1,027 respondents, omnibus study); and the second on Estonian companies' attitudes towards the Estonian brand (289 interviews). The first results revealed that image-building abroad was very important to people and that the sign is memorable (39\%), warm and friendly (32\%), and yet nondescript (34\%). Those who disliked the sign mentioned that it does not stand out or describe the country, and is not attractive. The second survey showed that Estonian businesses were highly familiar with the sign, but the majority said it had not played its expected role abroad (58\%), that it is nondescript (47\%) and associated with some negative aspects. Seventy per cent did not know about the existence of a brand manual or the opportunities for using the sign. They agreed on that Estonia needs to invest in branding because after six years, the image campaign would be exhausted.

Enterprise Estonia recognized the need to update the slogan and the rest of the brand concept developed in 2002, and declared in 2010 that developing a brand concept in 2008 was a matter or "evolution," not "revolution," rendering 
the visual side, including the sign WTE, and all the information researched on them, secondary (Välisministeeriumi aastaraamat, 2010). With the transition phase behind, innovation, openness, and development were the new features to emphasize. An expert workgroup combined efforts with international consultants on a workshop that resulted in the formulation of the slogan 'Positively surprising'. This is still the basic idea and message for the positioning of the Estonian brand (Fig. 1).

Figure 1. Sign "Welcome to Estonia" and slogan "Positively surprising".

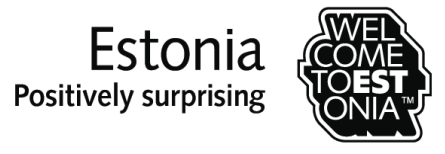

Small and relatively unknown countries greatly benefit from information dissemination initiatives. In 2008, the Estonian advertising agency Tank developed 'Introduce Estonia', a newer philosophy of Brand Estonia. It consists of a marketing concept with strategies on four focus areas. Tourism is the most important area in this context. The title of the marketing strategy to promote the country as a travel destination is "An Old Country in a Shiny Package" and it consists of an integral system for presenting the country. Four sub-strategiescultural, city, nature and wellness holiday - have identified special symbols of the country to support its promotion. ${ }^{5}$ In the concept, those symbols (objects, events, phenomena or landmarks) are the basic elements of stories or sources of inspiration for developing a topic in accordance with the 'Positively surprising' platform. Each sub-strategy comprises several symbols which are graphically represented in Figure 2.

One goal is to communicate the country as a memorable and an exciting travel destination to anyone through these symbols. The 'Introduce Estonia' concept's effectiveness also depends on how actively it is used. Enterprise Estonia claims that it can be developed and improved through constructive feedback and actual experience.

In 2012, an additional marketing strategy "A fresh and forward-looking nation" was launched for the business environment.

To sum up, Brand Estonia consists of conceptual strategies, the sign, slogan, pattern, colours, photography, typography, and brand communication. The sign

5 More detailed explanations on the strategies can be found online at: http://www.eas. ee/en/introduction-of-estonia/estonia-as-a-tourism-destination 
has not played its expected role abroad and is still the same, but in 2008 the slogan was changed from 'Positively transforming' to 'Positively surprising' and the pattern from folk embroidery to cornflowers. The concept has been developed over the years to promote Estonia through arguments and symbols, but customer-based research has been insufficient and mainly done applying quantitative methodologies.

Figure 2. Symbols by sub-strategies (adapted from marketing strategy for tourism). ${ }^{6}$

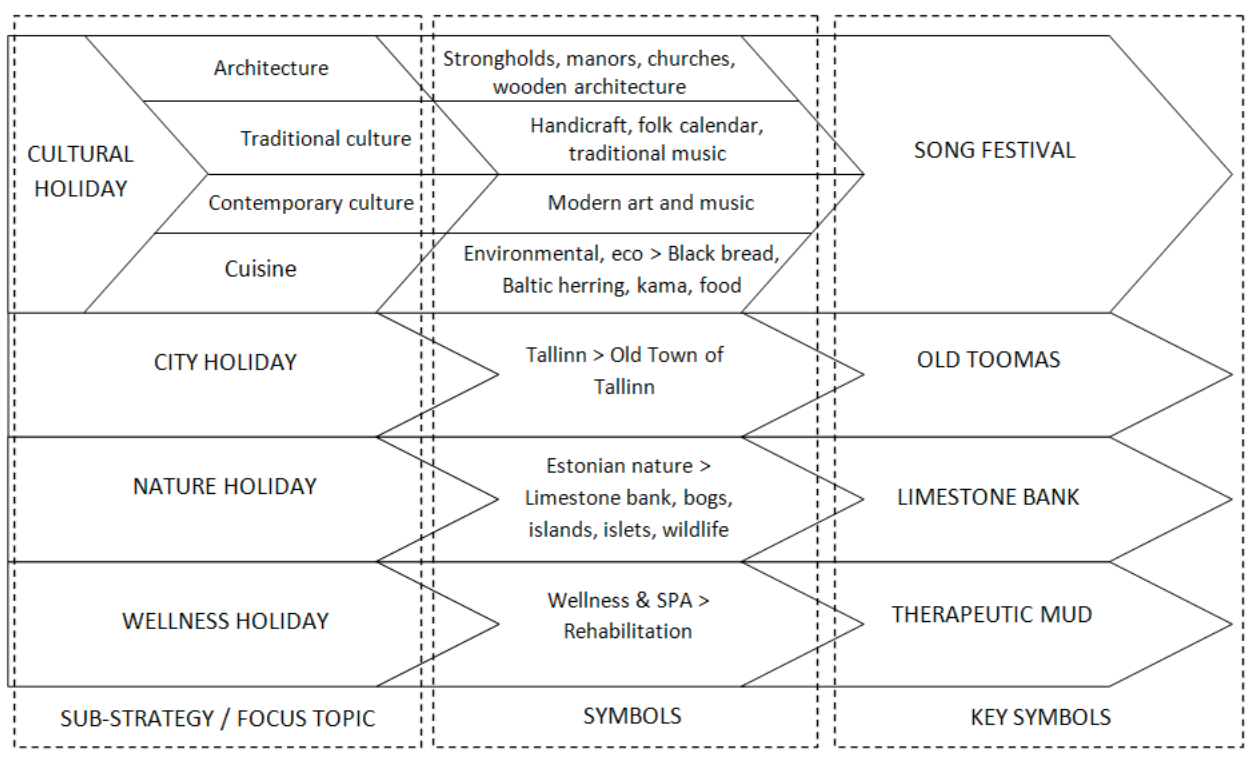

\subsection{Categorized interview report}

\section{Estonia's image}

The interviewees believe that in their countries, Estonia's image is good and that if people know about the country, it should be in positive terms. Tallinn is the most visible place in their opinion, and its Old Town is considered a valuable destination. It was repeatedly mentioned that Estonia is a world reference in technological terms: "Estonia is a tech-savvy society, technology is very advanced." Countries closer to Estonia, especially in Scandinavia, appear to have a more accurate perception of its potential and advantages, such as the quality of its food, the character of people, and the favorability of prices.

6 The strategy can be found online at: http://brand.estonia.eu/en/home/brand/ 
Freedom was a value noticed by some of the interviewees who suggested this should link to favorable conditions for entrepreneurship and business ventures. At the same time, they are familiar with negative aspects created by recent events in the Estonian history (the Soviet legacy: architecture, social problems, people's lifestyle, etc.).

In remote regions, interviewees believe that little is known about Estonia, apart from the fact that it is a small country with little if any influence in world affairs, but young, energetic and up to the challenge of rebuilding its self and its image. This knowledge has been increased by the media coverage of the recent economic crisis that ranked Estonia very well on its management and recovery among other European countries. However, the interviews did not elaborate with comments on the microeconomic level. Opinions about Estonians mostly had to do with the interviewee's personal experiences, therefore they contrast greatly and are difficult to summarize. Most noticeably, people are perceived as reserved and individualistic, with a cynical sense of humor, and too serious: "they could smile more often." At the same time, they are considered to be welcoming and industrious, active and enthusiastic. It is observed that the more superficial the contact with the country, the less criticism was expressed in the answers. It is possible that for this group of foreigners to interact with locals and to develop opinions is eased because communication in English and other languages in Estonia is not problematic: "Estonians are charming, they are friendly, very helpful, speak terrific English." In general, the image abroad is not homogeneous or fixed on special characteristics. When asked, about half of the interviewees could link Estonia with their Nordic neighbors, but the other half could not, referring to them as European, Baltic or Eastern European. The country continues to surprise visitors: many who have low or no expectations about it, later admit having had very positive experiences, liking the places they saw, the products it has on offer, and how clean and safe Estonia is. The airport and its neat appearance and efficiency, for instance, left to one of the interviewees such a good impression that conditioned his views on what was to come next. It was surprising that people appear to be very well off, compared to others in wealthy countries of Europe, as one comment indicated: "People, at least in Tallinn, seem to have better and newer cars than most of us [...]" The long sandy beaches and the flat topography were, for those who have traveled more extensively, also unexpected surprises. Many in the group mentioned the Estonian Song Festival. Some commented on the educational system that in their opinion is much better than they imagined.

Food in Estonia received very good reviews; not only seasonal produce, but also manufactured, processed food and that offered in restaurants. The mixture of 
modern and traditional, tasty, healthy, natural, and varied foods is appreciated by many. In several interviews, the sudden and steep rise in prices of the latest years came up, suggesting that it has been a discouraging sign for many tourists of countries were Estonia was promoted as a shopping destination.

\section{Estonian brand (Brand Estonia)}

The brand sign WTE was noticed by all but one of the people interviewed. All expressed negative opinions about it while only few could say anything positive or neutral, such as that it has been used consistently or could be considered "cute". Answers were similar in that the sign is old-fashioned, reminiscent of the 1960s or 1970s, too simple, and especially that its shape and message seemed random. The division of the words 'wel-come' and 'ESTonia' caused confusion, in particular to the English native speakers. Having to guess and decipher the sign annoyed people. They questioned the message: "Why welcome to Estonia when any country welcomes visitors? Is the contour supposed to be the map of the country? If so, who would possibly care about this?" An expert stated: "It is a mess, and doesn't say what it is trying to say. And it doesn't say anything new [...], it could be welcome [to] Australia or Fiji or what it happens to be. So I think it is over-complicated and a poor piece of communication." There were two instances in which the sign said nothing to the interviewee. This question reflected the least favorable opinions of all. The construct Brand Estonia (sign, pattern, slogan, selected colors, font style, etc.) appears to be more complicated for the interviewees to comment on. The pattern was noticed much less than the sign; the slogan remained unknown for the most part, although it sounded fine. When asked, most replies reverted to the previous question and repeatedly criticized the sign and its lack of readability; they called it amateurish, for its randomness or unclear communication scheme. Some argued that the brand was made from the Estonian perspective; one proposed to invest more inquiring about the image of Estonia abroad to be better able to understand and connect with the audience and modify the strategy. Brand Estonia did not seem innovative to the group; the cornflower was mistakenly taken as a snowflake, if noticed at all. Foreigners do not know that it is the national flower, and because it is not presented in its real colors, they cannot recognize it.

The title of the Estonian tourism strategy "An Old Country in a Shiny Package" was considered misleading, confusing, with negative connotations or simply disliked. While the word 'shiny' appeared to raise the most objections, interviewees also said that the country is not thought of as old. The experts believe that research is missing because the brand in general seems to be based 
on guessing, instead of knowing, what foreigners should like about Estonia, to better advertise, present and communicate the positive side of it and attract visitors: "the problem with Estonian tourism and tourism across a lot of destinations is not enough investment in research".

\section{Potential for country branding}

On branding cooperation - the possibilities to associate the country either with the other Baltic states or the Scandinavian neighbors - the responses were mixed. It is clear that collaboration reduces costs, and that differentiation can come later, through experience. Many visitors would not travel only to Estonia, if exploring the vicinity was not possible or on offer; this is how one interviewee explained it: "They would not travel this far, literally to the other side of the world, just to go to Estonia. We went to spend some time here, we went to Finland, Russia, Latvia, and Denmark." On the other hand, promoting Estonia independently was not objected, because they know well what differentiates this country from the rest. They suggested that other Baltic countries would benefit more from this cooperation than Estonia.

It was discussed in detail that to improve the branding strategy for Estonia, positioning in neutral markets is needed, as they have no fixed notions of what the country is like, and that detaching from the Eastern-European image could be more beneficial to that end. This is why associations to the NordicScandinavian image appeared to be more favorable than others, as one expert proposed: "I think that if you look at what tourism brand is then your strategy would be 'Nordic with a twist', I think is quite good. And certainly talking a bit about moving yourself away from the negativity associated with brand Eastern Europe." One mentioned that Tallinn is already regarded as the southern part of Helsinki.

Interviewees were aware of the need for a deliberate strategy and suggested to use disseminate information when promoting Estonia on: local products and singers; entertainment; people speak English; Christmas market; snow; surprising people and spaces; people are freedom- and nature-loving; alternative travel opportunities such as hunting; the historical experience; closeness to the Finnish culture; spas; diversity; advanced e-solutions; swamps; beaches; plenty of things to do; a potential test market and co-production site for investors; good food, etc. At the same time, it was recommended to unfold the country within, making it desirable for people to travel to cities other than Tallinn, such as Pärnu, Haapsalu, Narva or the islands. Words most linked to the country during the interviews were: nice, safe, organic, clean, authentic, small, vibrant, open, 
beautiful, comfortable, etc. The interviewees said that the words 'discover' and 'experience', as well as diverse information distributed in innovative formats, should raise the interest of potential visitors from countries far away. Suggestions for branding included: to turn Tallinn into the romantic capital of Europe; show that Estonia could be part of a wider tourism destination such as the Nordic area or the Baltics; do more customer-based research to understand the audience preferences; think of something not promoted anywhere yet; revise the current strategy; find a magnet for Tallinn; target the right audience; show the hightech capacity; promote with innovative phrases such as "let's go to Europe via Estonia" and "the undiscovered gem of Europe," etc.

It can be observed that the country has the opportunity and potential to attract more tourists than those identified so far, and that the strategy could be more dynamic and adaptable to different audiences. The need to disseminate more information, and make the country more appealing to the public, to compensate the lack of awareness and possible misconceptions about the country, was evident. Two branding experts commented: "Let's have probably a PR or strong media strategy or visiting journalists program strategy to try to shift some of those positions with different segments", "tourism marketing these days is incredibly scientific and layered", "the old days of saying let's go out and have one brand that is going to suit all markets does not really work anymore". Another thought that "We have solutions for you," referring to the Estonian technology capacity, would be a good slogan. A non-expert stated: "safety would be my number one concern, number two - the city and things to do, number three-comfort and uniqueness perhaps of hotels and accommodation". Better access to the regions, could create, in the opinion of the group, interest to discover different places of Estonia, its culture, heritage, and even its Soviet past.

\section{Estonian experiences}

The experiences of the interviewees had to do with their personal expectations and varied according to their place of origin and their links to Estonia, for the most part. They mentioned that the more intimate, one-to-one experience is always a much better option than appealing to mass tourism (like ferry tourism) possibility: "I would focus on personal stuff: farms, forest, sea, all sort of things personal like local person-to-guest experiences." For some of the interviewees, to visit local homes and to be at Estonian parties had a special appeal. When asked to describe a truly authentic Estonian experience, the Song Festival was the most common choice. Other examples were the Christmas market, cultural events, the islands, exotic manor houses and architecture, unique nature (swamps and sandy beaches with pine trees), IT development, the Old Town, a Russian 
feeling (resembling the Soviet times), saunas, driving on ice, something is always happening, fast changes, etc. In contrast, one expert associated an authentic Estonian experience with the word 'slow', in the sense of meaningful, relaxing and calm. Food was told to be a channel to communicate authenticity because it could deliver a really unique experience. Non-experts who were less familiar with experience marketing made also proposals that resemble this concept. The interviewees emphasized on the historic atmosphere, spas, exoticism of wild berries, ease of access to regional areas, etc. One person compared the country to an onion- - "every time there is something new to discover or something that surprises".

Most people in the group have promoted Estonia abroad talking about the country or answering questions when asked about it; all would recommend a visit. They anticipated that visitors would be positively surprised about Estonia. Many believe that the best promotion is made by the word of mouth so that visitors could become efficient disseminators of a positive image. One of the branding experts explained: "developing brand advocates, people who have spent time in your country and using/harnessing them [...], because people are going to believe what I say, my friends at a dinner party, more than picking up a brochure saying welcome to Estonia." Some said they would love to come back, few of them have moved here permanently. For these people, it was obvious that to understand people's experiences in Estonia is important to stage and deliver authentic Estonian experiences to all visitors, and attract more. A summarized visualization of the categories (I-IV) and subcategories (1-16) that formed during the analysis of the interviews is available in Table 1. 
Table 1. Categories, subcategories, and main codes (framework for future research).

I Estonian image (perceptions on the country)
1. Estonia
Very little is known, Tallinn, Old Town, freedom,
image is fine, small, vibrant, Soviet legacy,
technology, young, energetic, economic
success story, infrastructure, media, national
heritage, culture, history, land, art, leaders
2. People
Welcoming, active, helpful, friendly,
individualistic, too serious, cynical sense of
humor, speak languages

\section{Positive surprise about Estonia}

Old Town, good quality, improvements, clean and safe, sandy beaches, Song Festival, good English, food, airport, discovery time, snow, four seasons

4. Belonging (Nordic, Baltic or EEC)

Yes/no, co-branding is cost-effective, countries are different, multidestination strategy, euro, EU

III Potential for country branding

\section{Promoting Estonia}

Part of tourist packages, Nordic with a twist, Winter market, swamps, beaches, hightech, PR strategy, better communication, co-branding, regional promotion (e.g., Pärnu, Saaremaa), reasons to come

10. Possible key messages

Romantic capital of Europe, close to Finland and Sweden, "Let's go to Europe via Estonia", "the undiscovered gem of Europe", spa kingdom, nature, alternative possibilities (things to do), safe, freedom, e-Estonia, always surprising

\section{The story of Estonia}

How people describe Estonia, a story to tell others

\section{Recommendations on branding}

Customer-based research, offer what the audience wants, find right symbols, realistic identity formulation, target right audience, continuous monitoring, understand the audience first
II Brand Estonia (brand performance)

\section{Country branding activities}

Important and necessary, need for unique brand identity and positioning, promise, studies, brand ambassadors, government policy, DMO, PR, materials (ads, videos, brochures etc.)

\section{Sign 'Welcome to Estonia'}

60 s and 70 s, retro, disliked, difficult to read (EST-onia), old-fashioned, nondescript

\section{Brand attributes}

Ineffective sign, 'Positively surprising': surprising factor (slogan is accepted), pattern unnoticed or not recognized

\section{Meaning and connotations}

Based on the Estonian perspective alone, Estonian humor, negative associations of 'An Old Country in a Shiny Package', little information about the brand and the country

IV Estonian experiences (how to sell Estonian experiences and what is authentic)

\section{Personal experiences, expectations}

Cheaper, shopping, value for money, events, historic atmosphere, Soviet past, fast changes, folklore, countryside, sea, safe, Skype, working and living in Estonia, friendly people, local products, clean

\section{Experience marketing}

Experiential elements, differentiation, personal impressions, meaningful, relevant, wow customer experience, relaxation; what people think, feel and want about Estonia

15. The symbols of Estonia Associations, (see Fig. 2 and Discussion)

\section{Authentic Estonian experience}

Song Festival, Christmas Market, Old Town, nature, spa, food, manor houses, islands, capture the reality, unique propositions 


\section{Discussion}

Place marketing is a highly competitive field: destinations seek to develop and offer potential visitors competitive advantages and differentiating features that could set them apart from the rest and captivate or retain more tourism. Effective differentiation is thus a critical aspect in times when so many markets can simultaneously offer similar products that become substitutable (Pike, 2004; Morrisson, 2013). Pike and Page (2014) highlight, referring to Morgan, Pritchard, and Pride (2002), that it is estimated that National Tourism Offices all around the world are competing for only 30 per cent of the total of international travelers because the remaining 70 per cent of them are visiting only ten countries. In that sense, places are interchangeable and easily replaceable because people seek convenience and unique experiences. The offer is so vast that attracting visitors requires destinations to have a clear identity definition without which a brand will not stand the tests of time and competition (Pike, 2012).

The interviews confirmed that while Estonia is a country that people around the world know very little about, its image among visitors is positive. The group subject to the interviews have more information about the country than an ordinary traveler which indicates that to that extent, their experiences and perceptions are valuable to assess effectiveness. Also, their opinions on the perceptions of people in their countries are useful and reliable as they have traveled to Estonia several times and some of them are experts in the field of this study. It can be argued that this audience is not the priority for brand managers because they already have formed an image of Estonia and possess links with the country. Therefore, confirming their opinions on the public at large would be convenient, if combined with an exploratory research on preferences and expectations. The closer their country of origin is located, the more specific opinions they expressed. The reported impact of the country on people's minds is useful to capitalize on the visitors' interest and to correct possible misconceptions that could negatively affect Estonia abroad. Understanding customers is a key factor to develop and maintain a good branding strategy. Although the country brand has been operational for more than a decade, its promotion has had shortcomings from the beginning. At present, the concept 'Introduce Estonia' is a practical tool that should aid everyone interested in selling Estonia to foreign tourists. It provides leads and priorities for tourism promoters, but its conceptual communication fails to be appealing, clear and distinctive. Information is a key factor to take into account because major flaws could be corrected by simplifying concepts and improving the messages that reach the audience. 
Considering the theory and empirical research developed in the past decades on country branding, it appears that the planning stage in the Estonian case was weak from the start. The identity selection was not justified by a persuasive consideration of the stakeholders' interests. Enterprise Estonia commissioned some research and incorporated expertise into the branding project but studies were few, shallow and limited. The problems of this process became evident later, when the brand did not adapt to the rapid evolution of the country. Estonia became a member of the supranational system of the European Union and other international organizations that directly affected its status and capacity. The world has undergone dramatic technical, economic, social and political developments in the last years, and its domestic situation has substantially transformed as well. At the same time, new attributes and opportunities for the country have arisen, to better position the brand abroad, but they have apparently remained undetected. If a country develops, the brand should evolve with it. In this light, a work in constant progress would imply periodic revisions and continuous input from the institutions involved in its maintenance. Country branding requires coordinated efforts so the potential of the country and the sustainability of the brand can be expected. The state was last involved in the direct support of branding initiatives more than ten years ago. Presently, it funds no studies or participates in the development and maintenance of the brand. As this fundamental coordination is missing, it can be asserted that the Estonian strategy does not fit into Anholt's definition of place branding. Fragmented efforts and dissociated stakeholders are unlikely to keep the country brand on check and guarantee its effectiveness. Estonia and its brand cannot be actively supported by a public that knows nothing or little about them. For promotion, the choice of brand imagery has proven ineffective because the expected outcome was not achieved.

Some aspects of the Estonian brand have evolved, seemingly in disconnected and unstructured ways. While the sign WTE has become a static symbol, different promotional concepts were proposed in 2008 (see Fig. 2). The substrategies on tourism are represented by four key symbols. They were chosen as the most differentiating and competitive, but only the Song Festival (the key symbol of culture holiday) matched the opinions expressed during this study. The selection of key symbols did not tackle what people consider interesting or important, making it appear arbitrary. This could also indicate that the promotion of those symbols has not been effective. In any case, there is no persuasive reasoning that could explain why Old Toomas, limestone bank or therapeutic mud were determined to be interesting references or that they could be attractive and representing Estonia abroad. No evidence on that the target audience's mind was taken into account was detected during the documentary 
analysis either. Consequently, the country cannot expect high brand equity to take place. If to conceptualize brand equity as a combination of awareness, associations and appeal/interest in the country as this study has suggested, the Estonian brand managers face a serious challenge. A mismatch between the disseminated messages and the actual image about the country prevails among the different publics. In the interviewees' opinion, sandy beaches, forests and swamps were the preferred references on nature holiday; nobody spoke of limestone banks. Only few people from a country where wellness holiday is common showed interest in health-related visits, but with no mention of the therapeutic mud. Instead, in the opinion of the group, good organic and authentic food and the Estonian nature were common references that could be linked to wellness. Tallinn and its Old Town are well recognized and appreciated assets but Old Toomas (the key symbol of city holiday) remains unknown. If the brand concept had been addressed and examined from the perspective of the public, the strategy for tourism would have a clear effect on the consumers' image of the country. The lack of key symbol associations that consistently showed during the interviews indicates that customer-based research for the Estonian brand is still needed.

An effective promotion should be made on the grounds of objective and attractive attributes of a country, the unique services it offers and its best products, tailored to the customers it aims to attract. The Estonian brand places its hopes on what the brand managers think is a competitive and differentiated identity, but it does not hold on the public perceptions. Therefore, the real potential of the country to attact visitors is wasted.

Increasing the availability of information has been a way to affect potential visitors (brochures, books, videos, webpages, etc.), and yet it has had no verifyiable impact on the public that the interviewees represented. Many and mixed messages disconcert the audience. The whole brand concept is too complex, far-fetched, obscure and affected. A simpler set of strategies and messages, combined with an attractive sign could communicate more efficiently to the potential traveler as to what are the unique features the country has to offer. This is not a weakness in itself given that it allows for a constructive interpretation: the country has the opportunity to enhance its image after the selection of proper identity attibutes are made, and efforts are focused onto disseminating the assurance of quality touristic experiences. That "quality" should be linked to the needs, interests and expectations of a well studied market.

Experience marketing, closely related to place marketing, can help differentiating the country. Studies on what could be the authentic Estonian experience and 
how to promote it are necessary. These interviewees' proposals are not sufficient to elaborate on the matter. Instead, they suggest directions for further research: to explore more options, and select the most convenient for brand managers to focus on.

Also, despite support on co-branding, to assert its realistic advantages is not possible in the absence of more specific studies. However, it appeared to be that pursuing associations with regions nearby might be more feasible and less compromising on the countries and their national identities than to associate with one only, or few others. At the same time, the Baltic Sea Region (BSR) brand could be an overly ambitious project (Andersson, 2007) because it involves many countries, each with the potential for alternative destination brand strategies. ${ }^{7}$ Until now, Estonia is partly linked with the Eastern European image, but this reference was somewhat balanced. It does not have a strong Nordic or Scandinavian image yet, as the Baltic connotation often repeated. Joining efforts with bigger and better known countries such as Finland or Sweden should be convenient to promote multi-destination travel; people from remote places mainly visit Estonia when it is part of a bigger package. To what extent and which regional and bilateral associations or cooperation with other countries could facilitate or not the promotion of the Estonian brand abroad are questions that remain open, but experts persuasively argue that this will be the norm in the future. These are intriguing topics to complement this analysis.

The sign WTE received the most consistent reviews. It is the least effective promotion tool according to all the answers. The interviewees are the right public to evaluate its significance, because this sign was supposed to cater to a foreign audience. It reflects the most the mismatch between customer views and the brand. The unexplicable and unidiomatic division of the phrase requires great deciphering efforts, especially from the English native speaker. Someone could think that changing a sign that has been used for so many years could be risky, but to consider the costs of maintaining an ineffective sign for longer is more necessary. Proposing its replacement or update should not lack supporters given that from the beginning of the Estonian branding process this choice was highly controversial. More complete and independent research procedures, and assessments inside Estonia and abroad should appraise all related issues. Proposals on whether to reformulate this sign, and how to do it, cannot be implemented on the basis of the existing materials alone.

7 The BSR includes Denmark, Estonia, Finland, Germany, Latvia, Lithuania, Norway, Sweden, Poland and a part of Russia. 
In contrast, the slogan 'Positively surprising' has been a welcomed expression that resembles the experience of most of the interviewees. They all agreed on that the reality exceeded their expectations. The cornflower pattern was not objected but it requires more visibility.

This article subscribes to the idea that a strong country brand could contribute to the development of a country and the challenges of remaining competitive in the global market can be helped by the brand if it has been adequately assessed and managed (Kleppe \& Mossberg, 2006; Fetscherin, 2010). In this sense, country branding is a continuous responsibility; one value proposition for the world market is proven not enough. It is demonstrated that the emotional connection that could attract travelers and trigger the desire to experience the uniqueness Estonia has to offer cannot be formed before accurate and well-communicated information has reached its audience. Estonia's image is not settled among foreigners and particularly abroad where information about the country is scarce. Nevertheless, the incipient development is positive and the public is open to learn more about Estonia. It is necessary to rectify formulation mistakes from the past, inprove the dialog with the target audience, expand this research and take advantage of newer and more outreaching marketing opportunities. Furthermore, any assessment must aim first at studying people's experiences and obtain better understanding of their perceptions, associations and emotions about the country.

\section{Conclusions and prospects for future research}

Country branding strategies derive their strength from their responsiveness to customer needs, interests and expectations. In the case of Estonia, despite noticeable efforts to establish a differentiating brand identity, the formulation of a complete country brand strategy has been a challenge. This article emphasized that understanding the audience enables country brand managers to influence people's choices and effectively promote the country. This is a critical step that should have preceded the formulation of marketing strategies. It was also clarified that the selection of the identity should be realistic, unique, and consistent with the development of concepts and tactics. The Estonian brand concept is too complex, fragmented, abstract, and largely unknown, and this causes the image of the country not to be affected in the way intended. 
The following context-specific conclusions could be drawn:

1) Estonia is largely unknown abroad, but its image among visitors is mainly positive.

2) Sufficient understanding of what the target audience appreciates, needs and wants from Estonia as an attractive tourist destination is missing. Its potential is unexplored.

3) The selection of current brand concepts, identity and strategy for tourism, as well as the promotion of initiatives in support of the Estonian brand are not effective or sustainable.

4) The Estonian brand is not well monitored, maintained and enhanced over time, but must be.

5) Some of the most relevant stakeholders (for example foreigners, state) are not involved in the Estonian brand management and development, and play no meaningful role in supporting or disseminating the brand.

That the image of Estonia is not yet positioned abroad is a good opportunity to correct the detected shortcomings. Experience marketing could be applied to the country branding process.

This study phase is not without limitations. The most important of all lies in the reliability of a small sample group of highly qualified interviewees. The audience of a tourism strategy is wide so a random sample could be more appropriate, but still attending to priority markets first. The findings are not generalizable for two reasons: first, because a case study presents unique characteristics and second, because qualitative research works on the basis of subjective analysis.

To complete a proposal of practical application to improve the Estonian brand experience is not possible in a single article. Continuing the study is important, as well as considering a mixed methodological approach to handle big amounts of relevant data. A greater body of research can better justify the design of future marketing concepts, and for rigor and creditworthiness, it should be interdisciplinary. The perception of visual aspects of tourism brochures, and websites, for example, could be evaluated from the cognitive, affective, and conative perspectives. The next stage will continue to assess customer opinions but will concentrate on innovative ideas and alternatives about how to promote a truly Estonian experience for tourists. Later, the study group will be expanded also to cover a greater representation, and the instrument will emphasize on the interviews' subcategories. During the coding process other important gaps were 
identified. They could turn into primary components later. This is the way to go beyond the identification of problems to the formulation of proposals.

Enterprise Estonia (DMO) could benefit from the insights that this study has highlighted and improve the monitoring of the brand. The potential of this topic is remarkable alone or in collaboration with other disciplines. For example, in the interest of academic inquiry a comparative analysis could be made between the Estonian brand and countries facing similar challenges: small, remote, not very well known, etc. Also exploring the experience marketing in the communication of country brand concepts and destination promotion is a feasible way to contribute with original research based on the Estonian case study.

Siiri Same is a PhD candidate at Tallinn University of Technology (TUT). She is a sales and marketing manager at Äripäev, a member of the Bonnier Business Press Group, and is actively involved in organizing marketing conferences. She received her master's degree with honors from TUT on Business Administration in 2006 and has been a successful practitioner for over 15 years. She has also taught Brand Management to graduate students and contributes to academic activities at the university. Siri has worked for both the private and public sectors at institutions such as Enterprise Estonia, Swedbank, Kalev Chocolate Factory, and Santa Maria, and has been Head of Marketing and Communication at TUT. Her main fields of interest are place marketing, brand management, and experience marketing techniques. She currently focuses on country branding and customer experience management research.

Maria Claudia Solarte-Vasquez received her LLM degree from the Washington College of Law of the American University. She obtained a BA in law and political sciences from the Law Department of Universidad Pontificia Bolivariana in Medellín, Colombia. Her professional activity has developed in the field of international transactions and risk management. Since 1996 she has designed courses that incorporate preventive law approaches and alternative resolution methods for dispute resolution. For 16 years she has lectured ADR, introduction to law, comparative legal systems, and legislative policy, with focus on its convergence with technology and innovation. Internet governance has been the subject of her latest research. Her main concerns regard regulatory legitimacy and the limits of the rule of law doctrine. 


\section{References}

Aaker, D. A. (2002), Building Strong Brands, London: Simon \& Schuster.

Agarwal, S. \& Sikri, S. (1996), 'Country image: consumer evaluation of product category extension,' International Marketing Review, vol. 13, no. 4, pp. 44-55. http://dx.doi.org/10.1108/02651339610127239

Andersson, M. (2007), 'Region branding: The case of the Baltic Sea region,' Place Branding and Public Diplomacy, vol. 3, no. 2, pp. 120-130.

http://dx.doi.org/10.1057/palgrave.pb.6000057

Anholt, S. (2007), Competitive Identity: The New Brand Management for Nations, Cities and Regions, Basingstoke: Palgrave Macmillan.

Ashworth, G. \& Kavaratzis, M., eds. (2010), Towards Effective Place Brand Management: Branding European cities and regions, Cheltenham: Edward Elgar Publishing.

Beerli, A. \& Martin, J. D. (2004), 'Factors influencing destination image,' Annals of Tourism Research, vol. 31, no. 3, pp. 657-681. http://dx.doi.org/10.1016/j.annals.2004.01.010

Bellenger, D. N.; Bernhardt, K. L. \& Goldstucker, J. L. (2011), Qualitative Research in Marketing, Decatur: Marketing Classics Press.

Blain, C.; Levy, S. E. \& Ritchie, J. R. B. (2005), 'Destination branding: insights and practices from destination management organizations,' Journal of Travel Research, vol. 43, no. 4, pp. 328-338. http://dx.doi.org/10.1177/0047287505274646

Botterill, D. \& Platenkamp, V. (2012), Key Concepts in Tourism Research, London: Sage.

Braun, E. \& Zenker, S. (2010), Towards an Integrated Approach for Place Brand Management, Paper presented at the $50^{\text {th }}$ European Regional Science Association Congress, 19-23 August, Jönköping, Sweden.

Brown, T. J.; Dacin, P. A.; Pratt, M. G. \& Whetten, D. A. (2006), 'Identity, intended image, construed image, and reputation: an interdisciplinary framework and suggested terminology,' Journal of the Academy of Marketing Science, vol. 34 no. 2, pp. 99-106. http://dx.doi.org/10.1177/0092070305284969

Creswell, J. W. (2012), Qualitative Inquiry and Research Design: Choosing among five approaches, London: Sage.

Cuba, L. \& Hummon, D. M. (1993), 'A place to call home: Identification with dwelling, community, and region,' The Sociological Quarterly, vol. 34, no. 1, pp. 111-131. http://dx.doi.org/10.1111/j.1533-8525.1993.tb00133.x

Dinnie, K. (2008), Nation Branding: Concepts, issues, practice, Oxford: Butterworth Heinemann.

Elliot, S.; Papadopoulos, N. \& Szamosi, L. (2013), 'Studying place image: an interdisciplinary and holistic approach,'Anatolia: An International Journal of 
Tourism and Hospitality Research, vol. 24, no. 1, pp. 5-16. http://dx.doi.org/10.1080/13032917.2013.800281

Endzina, I. \& Luneva, L. (2004), 'Development of a national branding strategy: The case of Latvia,' Place Branding and Public Diplomacy, vol. 1, no. 1, pp. 94-105. http://dx.doi.org/10.1057/palgrave.pb.5990009

Erm, T. \& Arengu, M. M. (2003), Development of a National Brand: The case of the Estonian brand project, Working paper, Riga: Stockholm School of Economics in Riga.

Fetscherin, M. (2010), 'The determinants and measurement of a country brand: the country brand strength index,' International Marketing Review, vol. 27, no. 4, pp. 466-479. http://dx.doi.org/10.1108/02651331011058617

Folkes, V. S. (1988), 'Recent attribution research in consumer behavior: A review and new directions,' Journal of Consumer Research, vol. 14, no. 4, pp. 548-565. http://dx.doi.org/10.1086/209135

Garcia, J. A; Gomez, M. \& Molina, A. (2012), 'A destination-branding model: An empirical analysis based on stakeholders,' Tourism Management, vol. 33, no. 3, pp. 646-661. http://dx.doi.org/10.1016/j.tourman.2011.07.006

Gertner, D. (2011), 'Unfolding and configuring two decades of research and publications on place marketing and place branding,' Place Branding and Public Diplomacy, vol. 7, no. 2, pp. 91-106. http://dx.doi.org/10.1057/pb.2011.7

Gilmore, F. (2002), 'A country-can it be repositioned? Spain - the success story of country branding,' The Journal of Brand Management, vol. 9, no. 4/5, pp. 281-293. http://dx.doi.org/10.1057/palgrave.bm.2540078

Govers, R. \& Go, F. (2009), Place Branding: Virtual and Physical Identities, Glocal, Imagined and Experienced, Basingstoke: Palgrave Macmillan.

Hall, D. (1999), 'Destination branding, niche marketing and national image projection in Central and Eastern Europe,' Journal of Vacation Marketing, vol. 5, no. 3, pp. 227-237.

(2002), 'Brand development, tourism and national identity: the re-imaging of former Yugoslavia,' Journal of Brand Management, vol. 9, nos. 4/5, pp. 323-334. http://dx.doi.org/10.1057/palgrave.bm.2540081

Hankinson, G. (2009), 'Managing destination brands: establishing a theoretical foundation,' Journal of Marketing Management, vol. 25, nos. 1-2, pp. 97-115.

Hsieh, H. F. \& Shannon, S. E. (2005), 'Three approaches to qualitative content analysis,' Qualitative Health Research, vol. 15, no. 9, pp. 1277-1288. http://dx.doi.org/10.1177/1049732305276687

Hudson, S. \& Ritchie, J. R. (2009), "Branding a Memorable Destination Experience. The Case of 'Brand Canada'," International Journal of Tourism Research, vol. 11, no. 2, pp. 217-228. http://dx.doi.org/10.1002/jtr.720 
Kapferer, J. N. (2012), The New Strategic Brand Management: Advanced Insights and Strategic Thinking, $5^{\text {th }}$ edition, London: Kogan Page.

Kamakura, W. A. \& Russell, G. J. (1993), 'Measuring brand value with scanner data,' International Journal of Research in Marketing, vol. 10, no. 1, pp. 9-22. http://dx.doi.org/10.1016/0167-8116(93)90030-3

Kavaratzis, M. \& Hatch, M. J. (2013), 'The dynamics of place brands: An identitybased approach to place branding theory,' Marketing Theory, vol. 13, no. 1, pp. 69-86. http://dx.doi.org/10.1177/1470593112467268

Keillor, B. D. \& Hult, G. T. M. (1999), 'A five-country study of national identity: implications for international marketing research and practice,' International Marketing Review, vol. 16, no. 1, pp. 65-84.

http://dx.doi.org/10.1108/02651339910257656

Keller, K. (2008), Strategic Brand Management: Building, Measuring, and Managing Brand Equity, $3^{\text {rd }}$ edition, New Jersey: Prentice Hall.

Kleppe, I. A. \& Mossberg, L. (2005), 'Country Image: A Reflection of the Significance of the Other,' Advances in Consumer Research, vol. 32, no. 1, pp. 295-301.

Kotler, P. \& Gertner, D. (2002), 'Country as brand, product, and beyond: a place marketing and brand management perspective,' Journal of Brand Management, vol. 9, no. 4/5, pp. 249-261. http://dx.doi.org/10.1057/palgrave.bm.2540076

Mayring, P. (2000), 'Qualitative Content Analysis,' Forum: Qualitative Social Research, vol. 1, no. 2 (June). Retrieved from http://www.qualitative-research. net/index.php/fqs/article/view/1089/2385 [accessed 01 Mar 2011]

Moilanen, T. \& Rainisto, S. K. (2009), How to Brand Nations, Cities and Destinations: A Planning Book for Place Branding, Basingstoke: Palgrave Macmillan.

Morgan, N.; Pritchard, A. \& Piggott, R. (2002), 'New Zealand, 100\% pure. The creation of a powerful niche destination brand,' Journal of Brand Management, vol. 9, no. 4/5, pp. 335-354. http://dx.doi.org/10.1057/palgrave.bm.2540082

Morgan, N.; Pritchard, A. \& Pride, R. (2002), Destination branding - Creating the unique destination proposition, Oxford: Butterworth-Heinemann.

Morrison, A. M. (2013), Marketing and Managing Tourism Destinations, New York: Routledge.

Myers, J. H. \& Alpert, M. I. (1968), 'Determinant buying attitudes: meaning and measurement,' The Journal of Marketing, vol. 32, no. 4, pp. 13-20.

Nebenzahl, I. D. \& Jaffe, E. D. (1996), 'Measuring the joint effect of brand and country image in consumer evaluation of global products,' International Marketing Review, vol. 13, no. 4, pp. 5-22. http://dx.doi.org/10.1108/02651339610127220

Nicoletta, R. \& Servidio, R. (2012), “Tourists' opinions and their selection of tourism destination images: An affective and motivational evaluation," Tourism Management Perspectives, vol. 4, pp. 19-27. http://dx.doi.org/10.1016/j. tmp.2012.04.004 
Nikolova, M. S. \& Hassan S. S. (2013), 'Nation branding effects on retrospective global evaluation of past travel experiences,' Journal of Business Research, vol. 66, no. 6, pp. 752-758. http://dx.doi.org/10.1016/j.jbusres.2011.09.014

Papadopoulos, N. \& Heslop, L. A. (2002), 'Country equity and country branding: problems and prospects,' Journal of Brand Management, vol. 9, no. 4/5, pp. 294-314. http://dx.doi.org/10.1057/palgrave.bm.2540079

Patton, M. Q. (2002), Qualitative Research and Evaluation Methods, $3^{\text {rd }}$ edition, Thousand Oaks: Sage.

Pike, S. (2002), 'Destination image analysis: a review of 142 papers from 1973-2000,' Tourism Management, vol. 23, no. 5, pp. 541-549.

http://dx.doi.org/10.1016/S0261-5177(02)00005-5

(2004), Destination Marketing Organisations, Oxford: Elsevier.

(2007), 'Destination image literature: 2001-2007,' Acta Turistica, vol. 19, no. 2, pp. 107-125.

_ (2012), 'Destination positioning opportunities using personal values: Elicited through the Repertory Test with Laddering Analysis,' Tourism Management, vol. 33, no. 1, pp. 100-107. http://dx.doi.org/10.1016/j.tourman.2011.02.008

Pike, S. \& Page, S. J. (2014), 'Destination Marketing Organizations and destination marketing: A narrative analysis of the literature,' Tourism Management, vol. 41, pp. 202-227. http://dx.doi.org/10.1016/j.tourman.2013.09.009

Roth, M. S. \& Romeo, J. B. (1992), 'Matching product category and country image perceptions: a framework for managing country-of-origin effects,' Journal of International Business Studies, vol. 23, no. 3, pp. 477-497.

http://dx.doi.org/10.1057/palgrave.jibs.8490276

Same, S. (2012), 'Country Branding and Experience Marketing: A Perspective on Sensemaking and Cognition Theories,' Journal of International Scientific Publications: Economy \& Business, vol. 6, no. 3, pp. 286-303.

Stokols, D. (1995), 'The paradox of environmental psychology,'American Psychologist, vol. 50, no. 10, pp. 821-837. http://dx.doi.org/10.1037/0003-066X.50.10.821

Szondi, G. (2007), 'The role and challenges of country branding in transition countries: the Central and Eastern European experience,' Journal of Place Branding and Public Diplomacy, vol. 3, pp. 8-20. http://dx.doi.org/10.1057/palgrave.pb.6000044

Therkelsen, A. (2003), 'Imaging Places: Image Formation of Tourists and Its Consequences for Destination Promotion,' Scandinavian Journal of Hospitality and Tourism, vol. 3, no. 2, pp. 134-150. http://dx.doi.org/10.1080/15022250310003105

Välisministeeriumi aastaraamat (2010), 'The story of creating Brand Estonia,' Estonian Ministry of Foreign Affairs Yearbook, Tallinn: Estonian Ministry of Foreign Affairs.

Warnaby, G. \& Medway, D. (2013), "What about the 'place' in place marketing?" Marketing Theory, vol. 13, no. 3, pp. 345-363.

http://dx.doi.org/10.1177/1470593113492992 
Wetzel, F. (2006), 'Brand England,' Place Branding, vol. 2, no. 2, pp. 144-154. http:// dx.doi.org/10.1057/palgrave.pb.5990052

Yin, R. K. (2009), Case Study Research: Design and Methods, $4^{\text {th }}$ edition, Thousand Oaks \& London: Sage. 